\title{
COMPARISON OF TECHNIQUES FOR DIAGNOSIS OF MICROFILARIA IN SHEEP IN NINEVEH GOVERNORATE
}

\author{
E.S. HUSSEIN and S.S. AGHWAN \\ Department of Microbiology, College of Veterinary Medicine, \\ University of Mosul, Mosul, Iraq
}

Received: 18 February 2019; Accepted: 11 March 2019

\begin{abstract}
This study included diagnosis of microfilaria in sheep in different methods which it is Knott's concentration techniques and staining by Giemsa stain and staining by acridine orange fluorochrome in blood sample in Nineveh in Iraq. we examined 150 sheep blood sample the percentage of infection by Knott's concentration techniques is $64 \%$ and the result is comprised with the results of acridine orange fluorochrome is about $83 \%$ while the percentage of infection by Giemsa staining method is about $43 \%$ and summary of what we have reached that staining with acridine orange fluorochrome is the more efficient than other methods in microfilarial detection, as well as this study is the first by using acridine orange fluorochrome in sheep blood sample in country.
\end{abstract}

Key words: Microfilaria, diagnosis, sheep.

\section{مقارنة تقنيات تثخيص اليرقات الخيطية الاقيقة في الضأن في محافظة نينوى \\ اريناس سعدي حسين ، سرى سالم أغوان \\ E-mail: laythalkattan@yahoo.com_Assiut University web-site: www.aun.edu.eg}

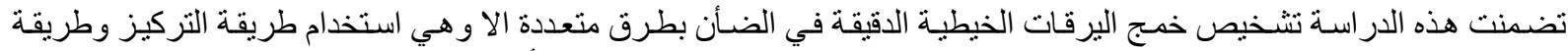

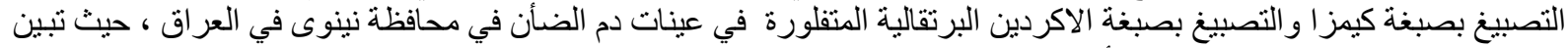

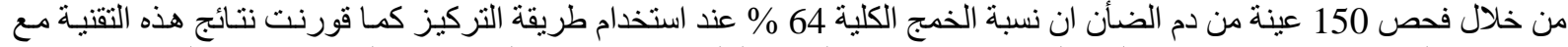

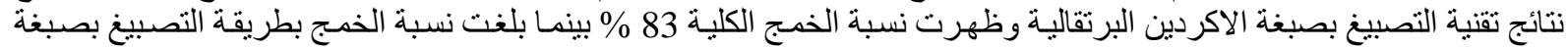

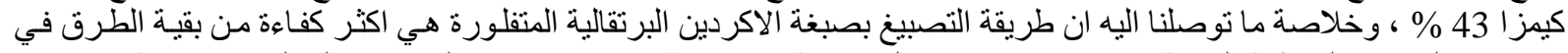

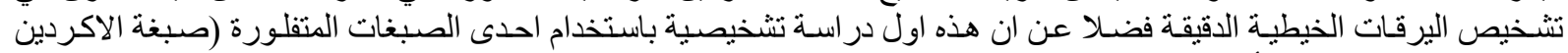
البرتقالية ) لعينات دم الضنأن في القطر الخدة.

\section{INTRODUCTION المقدمـــــة}

تستوطن اليرقات الخيطية الدقيقة الفلارية (Microfilaria) في الانسجة وجهاز الدوران للحيو انات الخمجة وتبدأ دورة حياتها غير

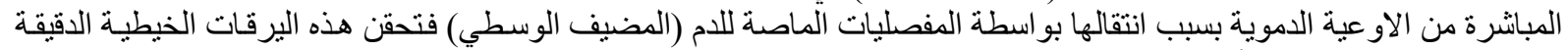

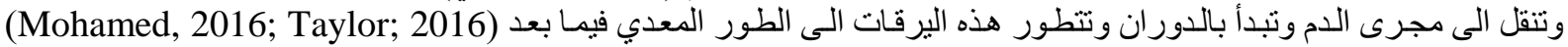

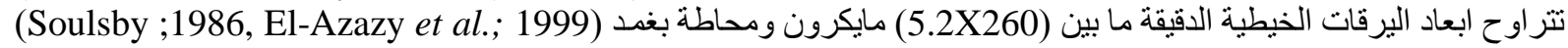

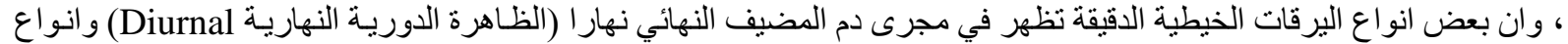

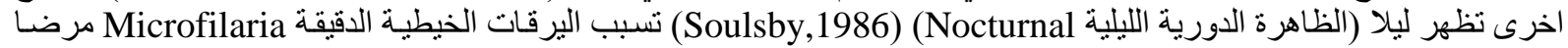

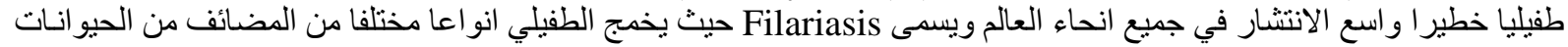

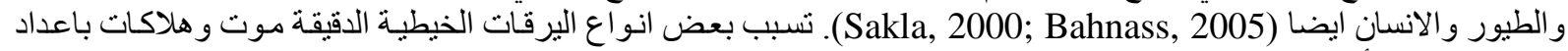

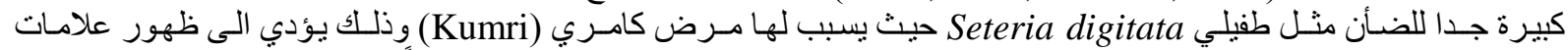

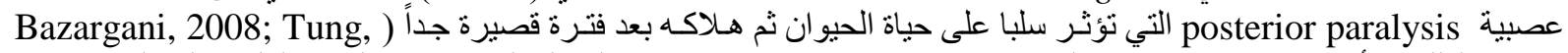

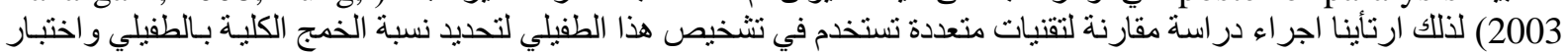
افضل التقنيات لاستخدامها في تشخيص اليرقات أنات الخيطية الدقيقة.

Corresponding author: Dr. E.S. HUSSEIN

E-mail address: laythalkattan@yahoo.com

Present address: Department of Microbiology, College of Veterinary Medicine, University of Mosul, Mosul, Iraq 


\section{MATERIALS AND METHODS المواد والطرائق}

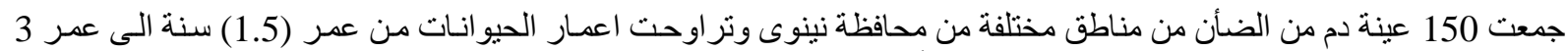

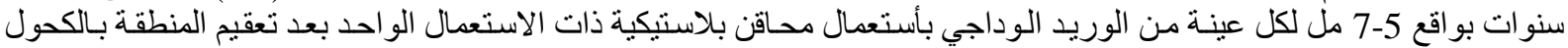

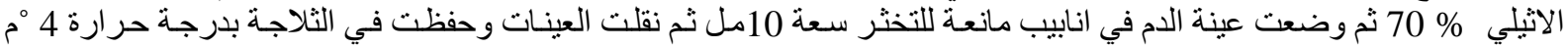

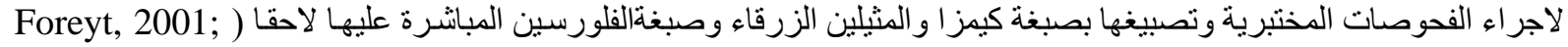

.(Thienpont et al.; 1986

الفحوصات المختبرية التي تجرى على عينات الدم :

knott's concentration technique (

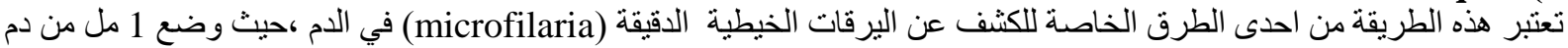

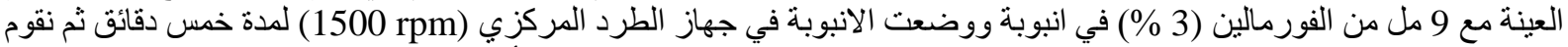

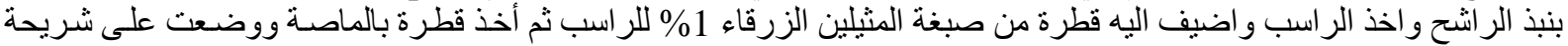

زجاجية ثم وضع الغطاء عليها وفحصها تحت المجهر الضوئي تحت قوة Francoise et al.; 1997) 40X , 10X , 4X).

Giemsa stain $(r$

وضعت قطرة من الدم على الثريحة الزجاجية و عملت مسحة دموية خفيفة وتركت لتجف لمدة 3 دقائق على الاقل ثم ثبتت بـت بالكحول

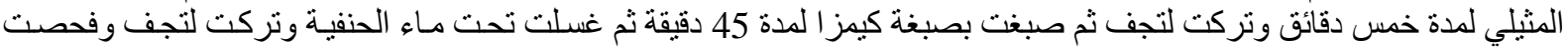

تحت المجهر الضوئي تحت قوة

Fluorescein stain (Acridine orange flurochrome) (r البر تقالية المتألقة ومنها:

أ-مسحة دموية سميكة

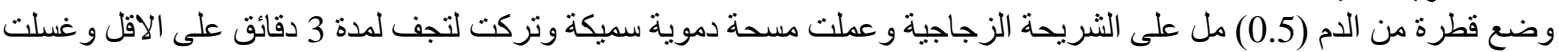

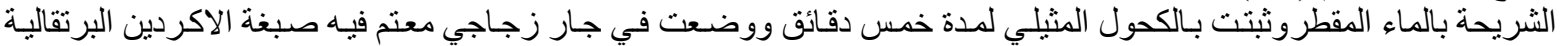

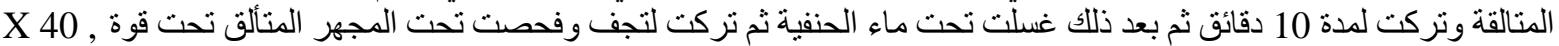

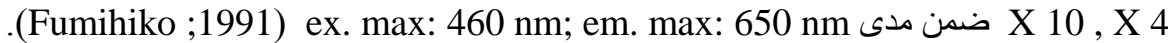

ب- مسحة دموية خفيفة

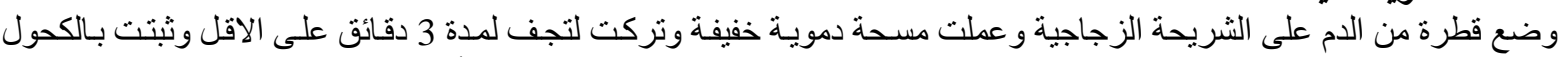

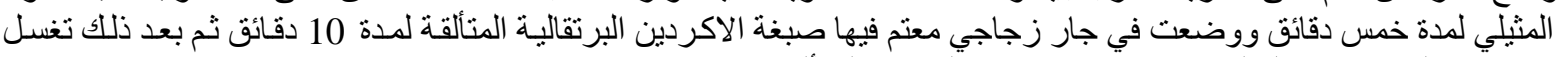

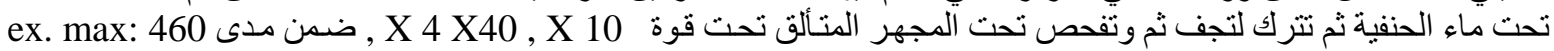
.Fumihiko ;1991) nm; em. max: $650 \mathrm{~nm}$

\section{RESULTS \\ النتائسج}

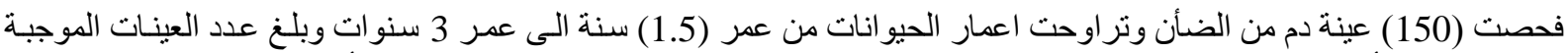

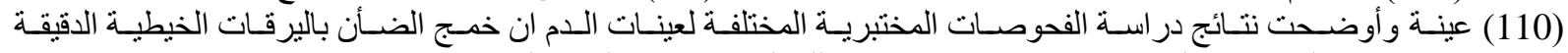
Microfilaria

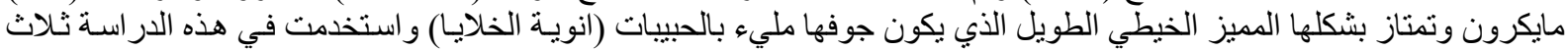

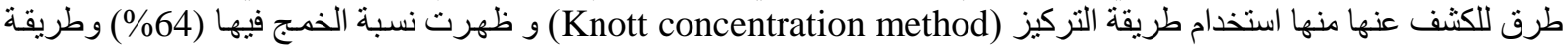

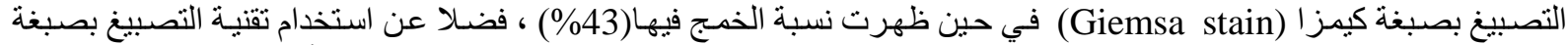

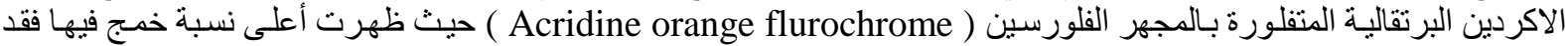

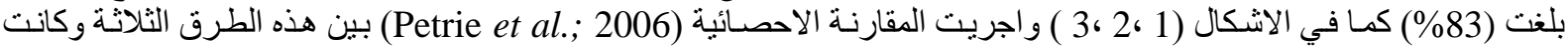

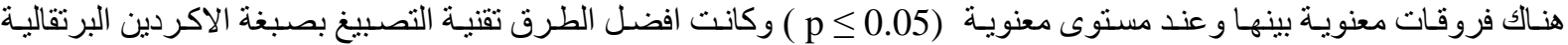

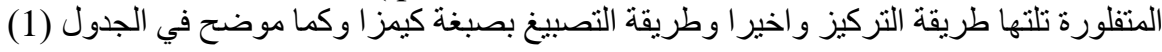




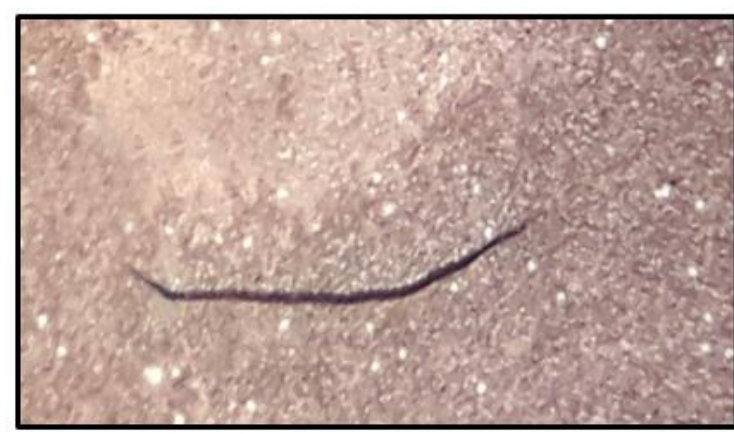

شكل (2) يرقة الديدان الخيطية الدقيقة باستخدام طريقة التصبيغ

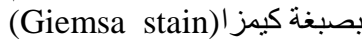
X 40 X 40 تحت قوة تكبير

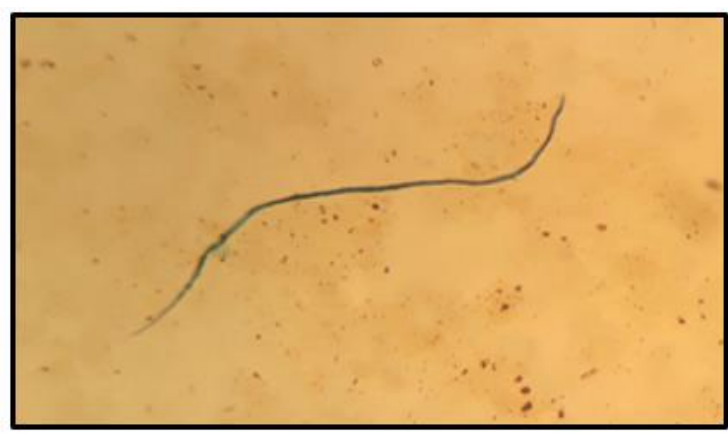

شكل (1) يرقة الديدان الخيطية الدقيقة باستخدام طريقة التركيز

(Knott concentration method) X

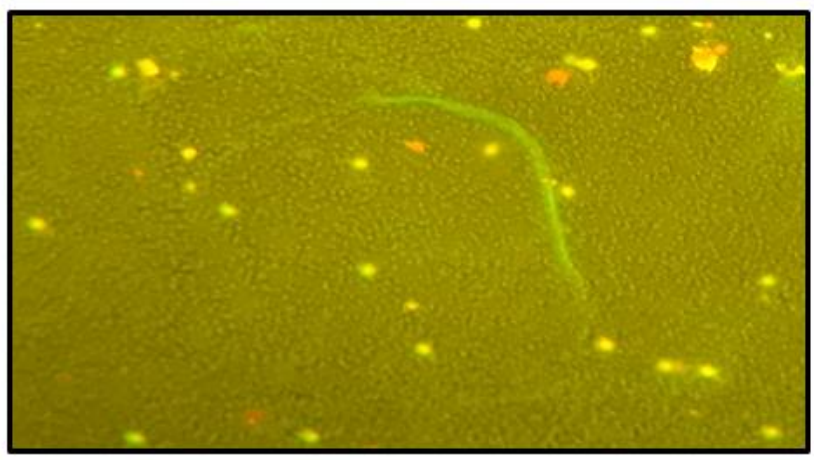

شكل (3) يرقة الديدان الخيطية الدقيقة باستخدام طريقة التصبيغ بصبغة الاكردين البرتقالية المتفلورة

X 40 تحت قوة تكبير (Acridine orange flurochrome)

جدول ا : يبين عدد العينات ونسبة الخمج لكل طريقة للكثف عن اليرقات الخيطية الدقيقة

\begin{tabular}{|c|c|c|c|c|}
\hline نسبة الخمج بطريقة التصبيخ بصبغة & بطريقة التركيز & التصبية الخمج بطريقة كبيزة & عدد العينات الموجبة & عدد العينات الكلية \\
\hline$\% 83$ a & $\% 64$ b & $\% 34$ c & 110 & 150 \\
\hline
\end{tabular}

\section{DISCUSSION}

المناقثة

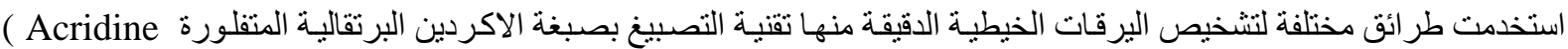
orange flurochrome )

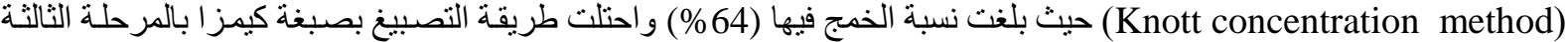

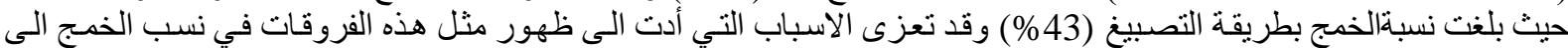

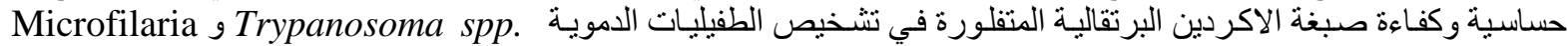

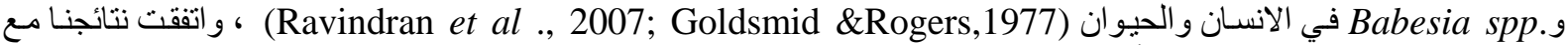

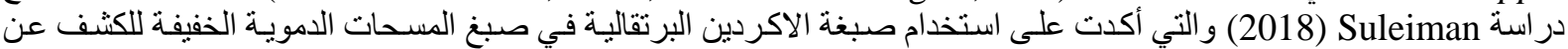

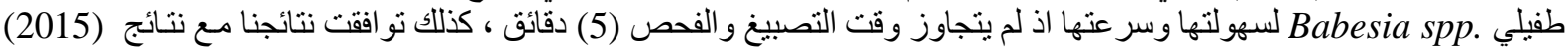
Yoon et al.

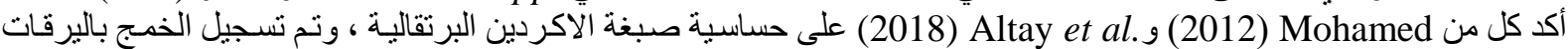

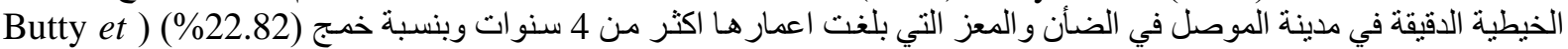

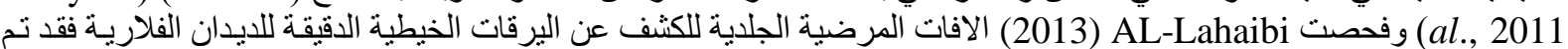

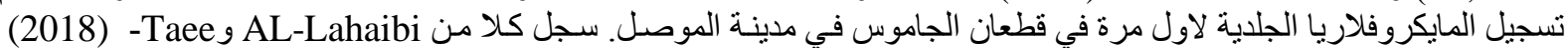

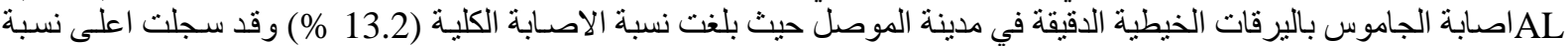

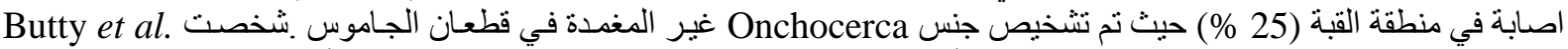

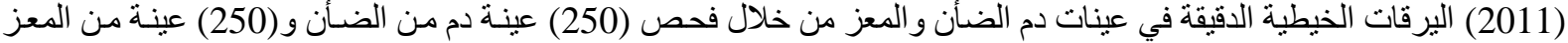

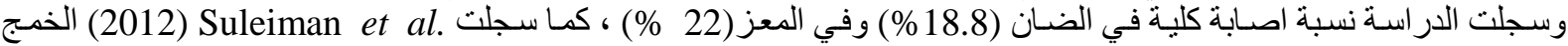

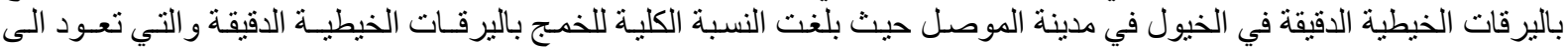

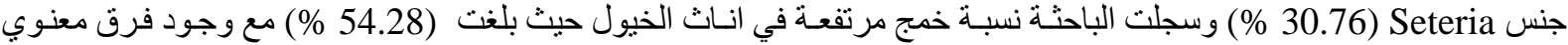
في نسبة الخمج بين الاناث و الذكور . 


\section{REFERENCES \\ المـراجع}

AL-Lahaibi, B.Y.M. and AL-Taee, A.F. (2018): Detection of Microfilaria in Buffaloes in Mosul city, Iraq. J. Falloja. volume 11. no.2

AL-Lahaibi, B.Y.M. (2013): Diagnostic study of Ectoparasites and Blood parasite in Buffalo in Mosul city. Msc Thesis, university of Mosul, College of Veterinary medicine, Mosul, Iraq.

Bahnass, MM. (2005): Studies on filariasis in some farm animals. Msc thesis, faculty of veterinary medicine, zaga zig University.

Bazargani, T.; Eslami, A.; Gholami, GR.; Molai, A.; Ghafart, J. and Ashrafi, J. (2008): Cerebrospinal nematodiasis of Cattle, sheep and goat in Iran. Iranian J parasitology: Vol 3, NO.1, PP. 16-20.

Butty, E.T.; Hasan, M.H. and AL-Taee, A.F. (2011): Diagnostic study of Microfilaria in blood samples of sheep and goats in Mosul city. Bas. J. vet. Res. vol.10, No.2.

EL-Azazy, O.M.E. and Ahmed, Y.F. (1999): Patent infection with Seteria digitate in goat in Saudi arabia: Vet. Parasitol. vol.82, No.2, 31; pp161-166.

Foreyt, W.G. (2001): Veterinary parasitology: reference manual. 5th ed., Iowa state university, press. USA. 8,9 .

Francoise Ardoin, Odile Bain; John Cross; Vida Dennis; Mark Eberhard; Robert Lowrie; Sri Oemiijati; Jean Pettithory and Purnomo and Lorenzo savioli (1997): Bench aids for the diagnosis of filarial infections, The World Health Organization, Departement of Epidemiology schoolof Public Health, University of California, Los Angeles, CA, USA.

Fumihiko Kawamoto (1991): Rapid detection of plasmodium by a new thick smear using Fluorescence Microscopy: Direct Staining with Acridine Orange, J. Protozoal Research Center in Japan, 1.27-34.

Petrie, A. and Watson, P. (2006): Statistics for Vet. and Animal Science. Blackwell Publishing.

Sakla, AA. (2000): Parasitological studies on filariasis in Assiut governoate. Assiut Med J; 24(1) 37-46.

Soulsby, E.J.L. (1986): Helminths, arthropods and protozoa of domesticated animals. 7th ed., Philadelphia, Bailliere Tindall, London.

Suleiman, E.G. (2018): Morphological \& Molecular study of Babesia spp. \& isolation \& diagnosis of tick vector in infected cattle in Mosul city, Ph.D. Thesis, University of Mosul, College of Veterinary Medicine, Mosul, Iraq, pp124-126.

Suleiman, E.G. and Al- Iraqi, OM. (2012): Detection of Microfilaria infection in horses in Mosul city. Iraqi J.Vet.Sci.26 NO. 2: 23-26.

Taylor, MA.; Coop, RL. and Wall, RL. (2016): Veterinary Parasitology, $4^{\text {th }}$ ed, Willey Black well.

Thienpont, D.; Rochette, F. and Vanparijs, O. (1986): Diagnosing helminthiasis through coprological examination. Janssen Foundation Beerse, Belgium.

Tung, Lc.; Lai, Ch.; Ooi, HK.; Yang, CH. and Wang, Js. (2003): Cerebrospinal seteriosis with Seteria marshalli and Seteria digitate infection in cattle. J. Vet Med Sci.; 65(9): 977-983.

Yoon, E.; Vail, E.; Sann, L. and Brass, J. (2015): New staining technique for diagnosising Babesia spp. American J. Clin. Pathol./44supp/ 2, 1: A 288, https://doi.org/10.1093/ajcp 